\title{
First report of leaf blight of Turkish oregano (Origanum onites) caused by Neoscytalidium dimidiatum in Turkey
}

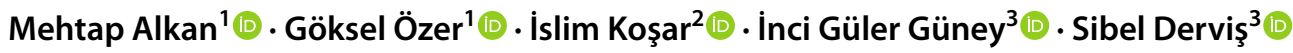

Received: 30 July 2021 / Accepted: 26 October 2021 / Published online: 4 November 2021

(c) Società Italiana di Patologia Vegetale (S.I.Pa.V.) 2021

Keywords Aromatic and medicinal herb $\cdot$ Oregano $\cdot$ Marjoram $\cdot$ Blight disease

In July 2020, a leaf blight disease with intense defoliation on Turkish oregano (Origanum onites L.) plants was observed in a pilot experiment field in Akçakale and a commercial field in Haliliye with an incidence of 5.4 and $11.7 \%$, respectively, in Şanlıurfa province. After a surface-sterilization for 1 min with $1 \% \mathrm{NaOCl}$, isolations from symptomatic tissues of six affected plants for each field consistently yielded a fungus with the same colony morphology on potato dextrose agar. Cultures were powdery with a thick aerial mycelium, initially white that changed from olive green to black within 10 days. All 12 isolates, each obtained from a different plant, produced dark-brown, thick-walled, cylindrical to oblong, zero to one-septa, and $9.7 \times 4.6 \mu \mathrm{m}(n=30)$ arthroconidia, both singly and in arthric chains. Pycnidia formed on pine needle agar were black, stromatic, and semi-immersed, with a mean diameter of $415 \mu \mathrm{m}$. Conidia formed in pycnidia were hyaline, oblong to globose, zero to one-septa, and $11.4 \times 4.8 \mu \mathrm{m}$ in length $(n=30)$. These characteristics were consistent with those of Neoscytalidium spp. (Phillips et al. 2013). The ITS and EF1- $\alpha$ loci of the isolate Nd01Tv were sequenced using primers ITS1/ITS4 (White et al. 1990) and EF1-728F/EF1-986R (Carbone and Kohn 1999), respectively. A BLASTn search of the sequences (GenBank Accessions Nos. MZ576552 and MZ593904) showed 99.87 and $100.00 \%$ identity with the ITS (MH861121) and EF1- $\alpha$ (KF531795) sequences of strain

Sibel Derviş

sibeldervis@gmail.com

1 Faculty of Agriculture, Department of Plant Protection, Bolu Abant Izzet Baysal University, Bolu 14020, Turkey

2 GAP Agricultural Research Institute, Şanlıurfa 63040, Turkey

3 Department of Plant and Animal Production, Mardin Artuklu University, Vocational School of Kiz1ltepe, Mardin 47000, Turkey
CBS 145.78 of $N$. dimidiatum. Phylogenetic analysis by the maximum likelihood method confirmed the identification. To establish the pathogenicity, the conidial suspension $\left(10^{6}\right.$ conidia/mL) of Nd01Tv was sprayed to leaves of 5 healthy 2 -year-old $O$. onites $\mathrm{cv}$. Oğuz plants. Five plants sprayed with sterile distilled water served as controls. All plants were maintained at $25^{\circ} \mathrm{C}$ with a $16-\mathrm{h}$ light/dark photoperiod. Two weeks after inoculation, leaf blight symptoms were observed on inoculated plants, whereas all control plants remained healthy. The pathogen was re-isolated from leaves of all inoculated plants and identified by morphological features, fulfilling Koch's postulates. To the best of our knowledge, this is the first report of leaf blight of Turkish oregano caused by $N$. dimidiatum in Turkey.

\section{References}

Carbone I, Kohn LM (1999) A method for designing primer sets for speciation studies in filamentous ascomycetes. Mycologia 91:553-556. https://doi.org/10.2307/3761358

Phillips AJ, Alves A, Abdollahzadeh J, Slippers B, Wingfield MJ, Groenewald JZ, Crous PW (2013) The Botryosphaeriaceae: genera and species known from culture. Stud Mycol 76:51-167. https://doi.org/10.3114/sim0021

White TJ, Bruns T, Lee S, Taylor J (1990) Amplification and direct sequencing of fungal ribosomal RNA genes for phylogenetics. In Innis MA, Gelfand DH, Sninsky JJ, White TJ (eds) PCR protocols: a guide to methods and applications. Academic Press, San Diego, pp 315-322. https://doi.org/10.1016/b978-0-12-372180-8. 50042-1

Publisher's Note Springer Nature remains neutral with regard to jurisdictional claims in published maps and institutional affiliations. 